JURNAL KETAHANAN NASIONAL

Vol. 26, No. 2, Agustus 2020, Hal 182-203

DOI:http://dx.doi.org/ 10.22146/jkn.53815

ISSN:0853-9340(Print), ISSN:2527-9688(Online)

Online sejak 28 Desember 2015 di :http://jurnal.ugm.ac.id/JKN

VOLUME 26

No. 2, Agustus 2020

Halaman 182-203

\title{
Aktualisasi Nilai-Nilai Pancasila \\ Sebagai Contoh Nyata Ketahanan Ideologi \\ (Studi di Kampung Pancasila, Dusun Nogosari, Desa Trirenggo, Kabupaten \\ Bantul, Daerah Istimewa Yogyakarta)
}

\author{
Isna Sari Rukmana \\ Universitas Negeri Yogyakarta, Indonesia \\ email: isnasari.2018@student.uny.ac.id \\ Samsuri \\ Universitas Negeri Yogyakarta, Indonesia \\ email:marzuki@uny.ac.id \\ Darto Wahidin \\ Pusat Studi Ketahanan Nasional, Indonesia \\ email: dartowahidin2@gmail.com
}

Dikirim: 27-01-2020; Direvisi:29-07-2020; Diterima:27-08-2020

\begin{abstract}
The development of Pancasila values was a very important thing to did on every side of life. This study aimed to determined how the development of the values of Pancasila in the Pancasila Village.

The method used in this study was a qualitative approach. The location in this study was in the Pancasila Village in Nogosari Hamlet, Trirenggo Village, Bantul Regency, Special Region of Yogyakarta. The informantion in this study were residents of Pancasila Village. The processed of retrieved data used observation, interview and documentation.

The results showed that the Pancasila Village in the Trirenggo Village was declared as the Pancasila Village in 2004. Activities were routinely carried out in developing Pancasila values in the Pancasila Village through mutual cooperation, consultation, discussion, collection of aid funds, routine social gathering, and deliberation. The values were developed in Pancasila Village through religious attitudes, tolerance, unity, deliberation, and social justice. The results of the development of the values of Pancasila were fairly good and got positive responses from local residents. The role of the community in developing Pancasila values by setting an example and accustoming good attitudes to reflected those who were Pancasilais. Pancasila village did not experience significant obstacles in developing the values of the Pancasila. Expectations desired by the community could maintain attitudes and habits derived from the values of the Pancasila.
\end{abstract}

Keywords: Values of Pancasila; Pancasila Village; Ideology Resilience. 


\begin{abstract}
ABSTRAK
Pengembangan nilai-nilai Pancasila merupakan suatu hal yang sangat penting untuk dilakukan pada setiap sisi kehidupan. Penelitian ini bertujuan untuk mengetahui bagaimana pengembangan nilai-nilai Pancasila di Kampung Pancasila.

Metode yang digunakan dalam penelitian ini dengan pendekatan kualitatif. Lokasi dalam penelitian ini berada di Kampung Pancasila di Dusun Nogosari, Desa Trirenggo, Kabupaten Bantul, Daerah Istimewa Yogyakarta. Informan dalam penelitian ini merupakan warga Kampung Pancasila. Proses pengambilan data penelitian dengan cara observasi, wawancara, dan dokumentasi.

Hasil penelitian menunjukkan bahwa Kampung Pancasila di Desa Trirenggo ini sudah dideklarasikan sebagai Kampung Pancasila pada tahun 2004. Kegiatan yang rutin dilakukan dalam mengembangkan nilai-nilai Pancasila di Kampung Pancasila dengan melalui gotong royong, musyawarah, diskusi, pengumpulan dana bantuan, arisan rutin, dan musyawarah kebangsaan. Nilai-nilai yang dikembangkan di Kampung Pancasila melalui sikap religius, toleransi, persatuan, musyawarah, dan keadilan sosial. Hasil pengembangan nilai-nilai Pancasila terbilang bagus dan mendapatkan respons yang positif dari warga sekitar. Peranan masyarakat dalam mengembangkan nilai-nilai Pancasila dengan memberikan teladan dan membiasakan sikap yang baik agar mencerminkan orang-orang yang Pancasilais. Kampung Pancasila tidak mengalami hambatan yang berarti dalam mengembangkan nilai-nilai Pancasila tersebut.Harapan yang diinginkan oleh masyarakat dapat mempertahankan sikap dan kebiasaan yang bersumber dari nilai-nilai Pancasila.
\end{abstract}

Kata kunci: Nilai-Nilai Pancasila; Kampung Pancasila; Ketahanan Ideologi.

\section{PENGANTAR}

Indonesia merupakan negara yang memiliki sumber daya alam, suku, agama, kepercayaan, hubungan dan budaya yang sangat kompleks dan beraneka ragam (Saputra,2017; Nurcahyono, 2018:106). Keanekeragaman tersebut tercipta dari kondisi bangsa Indonesia yang memiliki kesamaan dan perbedaan pemaknaan pada masing-masing karakter. Hal tersebut terbentuk berdasarkan kesamaan budaya atas nama suku, agama, dan unsur biologis yang menjadi ciri khas dan pembeda dari masing-masing kelompok (Kymlicka, 2003:4). Oleh sebab itu, kehidupan masyarakat yang tercipta dari persamaan dan perbedaan tersebut pada akhirnya menjadi gerakan inti yang menghadirkan simbol persatuan dan kesatuan yang tertera dalam Pancasila.

Keberagaman suku dan bangsa yang terjadi di Indonesia juga tidak lepas dari perubahan kondisi zaman. Hal ini ditandai dengan perkembangan di zaman dahulu yang memiliki keberagaman (Rozikin, 2019:2016).
Nilai-nilai tersebut bersumber dari budaya luhur yang menjadi penguat identitas nasional bangsa indinesia dan diwujudkan dengan sikap saling menghormati, sopan santun, dan tolong menolong (Sacipto,2018). Namun, pada perkembangan era revolusi industri seperti sekarang ini, keberagaman masyarakat mengalami pergeseran yang meluas dan memasuki setiap sektor dan tatanan kehidupan, termasuk kecanggihan teknologi digital, tatanan dalam berbangsa dan bernegara (Lonto,2019; Maharani dkk, 2019: 277). Hal tersebut ditandai dengan berubahnya pola pikir masyarakat yang semakin egois, pola hidup yang serba mudah dan cepat, berkomunikasi antara satu dengan yang lain, aktivitas kehidupan manusia yang semakin mudah dan praktis, perilaku masyarakat semakin konsumtif, melemahnya rasa kepercayaan satu sama lain, merebaknya hoaks, dan pemahaman generasi muda akan nilai-nilai luhur semakin hari semakin berkurang (Prasetyo, 2018; Wulandari, 2018; Raharjo dkk, 2017:176). Akibat yang ditimbulkan dari beberapa 
Isna Sari Rukmana, Samsuri, Darto Wahidin -- Aktualisasi Nilai-Nilai Pancasila Sebagai Contoh Nyata Ketahanan Ideologi (Studi di Kampung Pancasila, Dusun Nogosari, Desa Trirenggo, Kabupaten Bantul, Daerah Istimewa Yogyakarta)

fenomena tersebut memunculkan pergeseran nilai-nilai lama dan menggantikannya dengan teknologi baru.

Dewi dan Sunarso (2019:41) menyebutkan bahwa Pancasila sebagai dasar hukum, sumber nilai moral dasar, dan karakter bangsa yang bersifat fundamental pun tidak terlepas dari ancaman akibat era digital. Bahkan Widisuseno (2014:62) menyebutkan bahwa nilai-nilai yang berakar dari filosofi luhur para pemikir bangsa Indonesia ini menjadi semakin tergerus dan ditinggalkan. Hal itu dibuktikan oleh hasil survei yang dilakukan oleh Lembaga Survei Indonesia (LSI) tahun 2018 yang menyatakan bahwa masyarakat yang peduli terhadap ideologi Pancasila sudah mengalami penurunan secara signifikan sejak 10-13 tahun terakhir di 13 Provinsi di seluruh Indonesia (Viska, 2019). Penurunan tersebut mencakup pada berkurangnya pemahaman masyarakat akan nilai-nilai dan norma yang berlaku tentang bagaimana hubungan antar manusia satu dengan yang lain dalam kehidupan seharihari, yang sesuai dengan ideologi negara, yaitu Pancasila (Setiawan, 2018). Masyarakat Indonesia lebih menikmati kebudayaan luar negeri seperti: K-POP dan nilai-nilai barat. Hal ini mengakibatkan kesenian-kesenian daerah seperti ludruk, ketoprak, wayang, gamelan, dan tari-tarian tradisional lainnya menghadapi ancaman sangat serius dari kepunahan yang disebabkan oleh kelalaian masyarakat sendiri (Mubah, 2011). Nilai-nilai kebaikan seperti sikap saling menghargai dan satu sama lain maupun kepada yang lebih tua turut digempur kekuatan arus teknologi dan informasi secara luas, sehingga menyebabkan sikap individualistik dan konsumerisme yang diakibatkan oleh perkembangan tersebut semakin menguat dan melemahkan karakter asli Indonesia (Asmaroini, 2016; Siregar, dkk, 2019:1). Padahal seharusnya, nilai-nilai luhur Pancasila menjadi sumber penting bagi pemersatu keberagaman, pembentukkan karakter dan moral nasional (Sukmayadi, 2018; Rivelino, 2017).

Dewasa ini juga, sering menyaksikan dari fenomena intoleransi politik dengan menggunakan isu suku, agama, rasa, dan antargolongan (SARA) (Budiwibowo, 2016). Belum lagi terjadinya degredasi moral yang mengakibatkan merosotnya akhlak dan moralitas elit bangsa serta penghianatan terhadap Pancasila menyebabkan terjadinya eksklusivisme kelompok, ketidak pedulian pada kesenjangan pembangunan, merebaknya praktik korupsi pada semua cabang kekuasaan, dan sistem politik yang berbasis pada ikatan primordialisme menjadi semakin merajalela, dan tindakan-tindakan provokasi melalui sosial media sangat banyak di berbagai berita, baik di media cetak maupun radio, hingga media televise (Winarno dan Raharjo, 2018). Oleh karena itu, kebutuhan bangsa untuk menjabarkan rumusan-rumusan nilai dan norma, merevitalisasi, melaksanakan, memasyarakatkan, mendidik dan bahkan membudayakan Pancasila dan UndangUndang Dasar Negara Republik Indonesia tahun 1945 pada segala sisi kehidupan berbangsa dan bernegara merupakan tugas dan tanggungjawab bersama baik masyarakat maupun pemerintah (Huda, 2018:2). Pemerintah sebagai wakil rakyat tidak boleh melepaskan tanggungjawab dengan hanya memberikan bantuan dan dukungan kepada lembaga legislatif ataupun lembaga yudikatif untuk memasyarakatkan Pancasila dan Undang-Undang Dasar Negara Republik Indonesia tahun 1945. Masyarakat sebagai bagian dari pelaksana juga tidak boleh 
melepaskan tanggungjawabnya untuk tetap berlandaskan Pancasila dalam kehidupan sehari-hari (Anggusti, 2019:3).

Perwujudan nyata yang dapat dilakukan untuk mencintai Pancasila dapat dilakukan dalam berbagai macam bentuk, secara formal tentu dimasukkan dalam setiap peraturan. Pancasila dapat dimasukkan dalam setiap pembelajaran di sekolah. Keteladanan guru, dan membuat suatu wadah untuk lebih membumikan Pancasila dalam lingkup sistem sosial (Latif, 2018). Wujud dari sistem sosial tersebut dapat diwujudkan pada lingkup sistem nilai, sistem sosial, dan wujud fisik baik dalam kebudayaan maupun kehidupan masyarakat (Kaelan, 2013). Salah satunya ada di Kampung Pancasila yang dapat dijadikan sebagai sarana yang tepat untuk memupuk kembali nilai-nilai religius, nasionalisme, gotong-royong, mandiri, dan musyawarah yang bersumber pada Pancasila (Koran Sindo, 2019). Berdasarkan hal tersebut, permasalahan yang ingin dijawab dari penelitian ini terkait bagaimana pengaktualisasian nilai-nilai Pancasila di Kampung Pancasila; hasil pengembangan dari nilai-nilai Pancasila; dan kendala yang dihadapi dalam pengembangan nilai-nilai Pancasila di Kampung Pancasila.

Penelitian yang terkait dengan Pancasila maupun nilai-nilai yang terkandung di dalamnya amat-amat banyak (Adi, 2016; Asmaroini, 2016; Budiwibowo, 2016; Damanhuri dkk, 2016; Kariyadi, dan Suprapto, 2017; Rivelino, 2017; Saputra, 2017; Wulandari, 2018; Maharani dkk, 2019). Namun, penelitian yang memberikan contoh nyata dari pengembangan nilai-nilai Pancasila tersebut pada sebuah kampung yang kemudian diberi nama Kampung Pancasila amat langka. Maka dari itu, penelitian ini memberi suatu hal yang berbeda dengan penelitian sebelumnya, bahwa penelitian ini melihat sisi lain dari sebuah pengembangan nilai-nilai Pancasila yang terjadi nyata di Kampung Pancasila. Kampung Pancasila yang berada di Daerah Istimewa Yogyakarta ini digagas oleh dosen Pancasila yang berasal dari Fakultas Filsafat, Universitas Gadjah Mada. Selama ini Universitas Gadjah Mada mendapat julukan sebagai Universitas Pancasila yang ada di Indonesia karena civitas akademika berjiwa luhur dari nilai-nilai Pancasila.

Nilai pada hakikatnya sifat atau kualitas yang melekat pada suatu objek, bukan objek itu sendiri (Kaelan, 2002, 123). Objek yang dimaksud dalam hal ini Pancasila. Maka Pancasila mengandung nilai karena adanya sifat atau kualitas yang melekat pada Pancasila itu sendiri (Sudjana, 2018:136). Butir-butir yang terkandung dalam Pancasila mempunyai bobot yang berbeda, namun hal tersebut tidak saling bertentangan satu dengan lainnya. Pernyataan tersebut juga diperkuat oleh pendapat Max Scheler bahwa nilai-nilai yang ada, tidak akan sama luhurnya dan sama tingginya (Kaelan, 2002: 124). Sesungguhnya nilai-nilai yang terkandung dalam sila I-V pada Pancasila merupakan sebuah citacita, harapan, impian, dan dambaan Bangsa Indonesia yang harus diwujudkan dalam kehidupannya. Pengembangan nilai-nilai Pancasila berkaitan dengan sifat atau kualitas kehidupan masyarakat sehari-hari.

Dengan multidimensi berbagai macam penyebab dari krisis, maka usaha pembudayaan Pancasila harus dilakukan dengan melibatkan multi-approaches, multidisciplines, multimedia, multi-platforms, dan multi-stakeholders (Latif, 2018: 19). Maka diperlukan pendekatan yang harus lebih responsif dan atraktif dengan generasi milenial saat ini melalui pengembangan terhadap 
Isna Sari Rukmana, Samsuri, Darto Wahidin -- Aktualisasi Nilai-Nilai Pancasila Sebagai Contoh Nyata Ketahanan Ideologi (Studi di Kampung Pancasila, Dusun Nogosari, Desa Trirenggo, Kabupaten Bantul,

Daerah Istimewa Yogyakarta)

nilai-nilai yang terkandung di dalamnya. Pengembangan bukan hanya sebatas retorika semata namun juga diperlukan aksi melalui media sosial yang merupakan jelmaan dari kemajuan sebuah teknologi. Pancasila juga harus tetap menjadi sabuk pengikat bagi elemen bangsa yang sekian lama telah mendiami Nusantara (Al-Jihad, 2018: 159).

Saat ini Pancasila yang merupakan ideologi Negara Indonesia telah digoyahkan dengan berbagai tantangan baik dari luar maupun dalam. Hal ini ditunjukkan dari sebuah data yang dikeluarkan oleh Lembaga Ketahanan Nasional melalui surveinya yang dilakukan oleh Indeks Ketahanan Nasional Indonesia (IKN) telah mengalami penurunan tahun 2014-2015 pada gatra ideologi. Pada tahun 2014 indeks gatra ideologi berada pada kisaran 2,30 menjadi 2,23 pada tahun 2015 (Armawi dan Wahidin, 2018: 6). Salah satu penyebab dari kurang tangguhnya gatra ideologi setiap tahunnya karena yang pro dengan Pancasila sebagai ideologi negara mengalami penurunan dibandingkan dengan yang kontra atau yang ingin mengganti ideologi Pancasila dengan ideologi Islam katakanlah khilafah misalnya.

Wajarlah jikalau Pancasila goyah kemudian mengalami penurunan dari gatra ideologi yang merupakan bagian dari astagatra sebagai sebuah model yang ada dalam ketahanan nasional. Gatra ideologi dipengaruhi oleh faktor-faktor sebagaimana yang dijelaskan Armawi (2019: 78), nilai dan sistem nilai yang dianut oleh masyarakat secara ampuh akan menjamin keberlangsungan dari suatu ideologi yang dianut oleh negara. Bahkan suatu negara dapat runtuh jika tidak ada lagi kepercayaan dari ideologi yang dianut dalam masyarakat suatu negara tersebut. Konflik yang terjadi dalam suatu negara juga bisa disebabkan karena pertentangan yang terjadi berkaitan dengan ideologi yang berbeda-beda dan tidak bisa menyatuhkannya ideologi masyarakat yang dianut tersebut.

Metode penelitian yang digunakan dalam penyampaian hasil penelitian ini menggunakan pendekatan kualitiatif, yang menggunakan pengambilan data melalui observasi, wawancara, dan dokumentasi sebagai alat pengumpul data dalam penelitian di Kampung Pancasila sebagai sebuah contoh nyata aktualisasi nilai-nilai Pancasila. Penelitian ini dilakukan di Kampung Pancasila, Dusun Nogosari, Desa Trirenggo, Kabupaten Bantul, Daerah Istimewa Yogyakarta yang di dalamnya terdapat berbagai kegiatan dan program berkenaan nilai-nilai Pancasila. Hasil pengambilan data yang diperoleh ini dianalisis dengan menggunakan model Miles dan Hoberman, yaitu: teknik reduksi data, penyajian data, kesimpulan dan verifikasi, kemudian diverifikasi dengan teknik triangulasi sumber dan teknik.

\section{PEMBAHASAN}

Perkembangan era revolusi industri 4.0 yang membawa dampak yang sangat serius terhadap pengaruh masuknya digitalisasi dan disrupsi, serta eksistensi bangsa dan negara di dunia, khususnya Indonesia. Oleh karena itu, ketika segenap elemen kebangsaan tidak permasalahan ini sebagai suatu hal yang serius, maka maka hal tersebut menjadi celah untuk negara beserta komponen yang turut didalamnya akan mengalami kehancuran secara perlahan-lahan (Kaelan, 2015: 2627). Proses perubahan pada era ini menjadi suatu tantangan yang akan dihadapi oleh semua negara yang ada di belahan dunia, tak terkecuali Indonesia. Akibat dari pengaruh globalisasi yang tak dapat dielakkan dan 
akan berpengaruh pada strategi yang terkait pada keseluruhan elemen penting dalam lingkungan luas wilayah, negara, dan daerah (Latif, 2011:226).

Dampak yang akan ditimbulkan dari permasalahan ini pun dapat bersifat kontradiktif, artinya permasalahan tersebut akan memberikan hambatan, dampak positif dan dampak negatif tak terkecuali pada perkembangan nilai-nilai Pancasila pada seluruh elemen yang ada dalam masyarakat. Dampak tersebut akan mengubah pola pikir (mindset) masyarakat terutama generasi muda, cara bersikap, ketergantungan pada aplikasi dan perubahan digital, dan cara pengambilan keputusan dalam kehidupan (Kiel dkk, 2017:2). Oleh karena itu, diperlukan adanya upaya nyata yang dilakukan untuk merevitalisasi nilai-nilai Pancasila sebagai ideologi negara tersebut kedalam setiap sisi masyarakatnya. Salah satunya adalah dengan membuat suatu komunitas seperti kelurahan ataupun kampung Pancasila yang mengaktualisasikan nilai-nilai Pancasila dalam kehidupan sehari-hari.

Istilah Kampung Pancasila bukan merupakan suatu istilah baru dalam penataan geografis di Indonesia. Istilah ini merupakan bagian dari pengembangan dan penataan dari desa yang ada dalam Peraturan Menteri Dalam Negeri Republik Indonesia No 81 Tahun 2015 Tentang Evaluasi Perkembangan Desa dan Kelurahan. Melalui peraturan inilah akhirnya keberadaan kampung Pancasila menjadi semakin dikenal dalam lingkungan masyarakat luas. Kampung Pancasila mulai mengaung kembali setelah pada tahun 2018, Kelurahan Tebing Tinggi, Jambi dinobatkan oleh Kemandagri sebagai salah satu kelurahan Pancasila yang menjadi kelurahan/desa percontohan berkaitan pengaktualisasian nilainilai Pancasila secara nyata dalam lingkungan sehari-hari. Kemudian di canangkan juga kepada Kampung Pancasila yang ada di Desa Trirenggo, Kabupaten Bantul, Daerah Istimewa Yogyakarta yang disebut memiliki pengaruh-pengaruh signifikan terhadap kehidupan masyarakatnya.

Akibat yang ditimbulkan dapat dilihat dari eksistensi nilai-nilai Pancasila yang ada di daerah Kampung Pancasila yang selain dapat menjaga keutuhan persaudaraan, juga turut menjaga ketanahan ideologi bangsa agar tetap utuh dan mempertahankan nilai-nilai baik yang sudah dibiasakan di lingkungan tersebut (Fitriasari, 2019:411). Sehingga pada akhirnya, dikarenakan hal tersebut masyarakat luas dapat meniru dan melaksanakan kebiasaan-kebiasaan baik dan memiliki semangat (spirit) komunalitas dan partisipasi atau dedikasi sama seperti masyarakat yang ada di Kampung Pancasila, khususnya di Desa Trirenggo, Kabupaten Bantul, Daerah Istimewa Yogyakarta.

\section{Pengaktualisasian Nilai-Nilai Pancasila Di Kampung Pancasila}

Secara umum, kampung Pancasila di Indonesia memiliki sejarah yang panjang. Istilah Kampung Pancasila ini secara masif dikenal oleh masyarakat luas sejak tahun 2018. Dimulai dari pengikraran Kelurahan Tebing Tinggi di Kota Jambi sebagai kampung percontohan dalam pengaktualisasian nilai-nilai Pancasila. setelah itu barulah beberapa kelurahan lain di berbagai kota turut mengikrarkan diri sebagai Kampung Pancasila. Salah satunya adalah Daerah Istimewa Yogyaarta yang turut merintis salah satu bagian dari desanya sebagai Kampung Pancasila.

Keadaan masyarakat yang majemuk ada di Daerah Istimewa Yogyakarta, terutama 
Isna Sari Rukmana, Samsuri, Darto Wahidin -- Aktualisasi Nilai-Nilai Pancasila Sebagai Contoh Nyata Ketahanan Ideologi (Studi di Kampung Pancasila, Dusun Nogosari, Desa Trirenggo, Kabupaten Bantul, Daerah Istimewa Yogyakarta)

di wilayah Kabupaten Bantul memang dikenal sebagai masyarakat yang memiliki tingkat keberagaman yang cukup tinggi. keberagaman yang ada di daerah tersebut mampu menciptakan persatuan, kesatuan, dan keharmonisan bagi sesama pemeluk agama maupun antar umat beragama. Salah satunya adalah Daerah Istimewa Yogyakarta yang sampai saat ini menjadi potret kebhinekaan dan kebersaman yang sangat erat terjalin dari masa ke masa. Kampung Pancasila merupakan gagasan yang muncul setelah era reformasi tahun 1998. Istilah Kampung Pancasila dikenal dengan Dusun Pancasila bukan hanya muncul karena masyarakatnya yang memang hafal butir-butir dari setiap sila yang ada dalam Pancasila. Melainkan kampung tersebut juga hadir sebagai wujud nyata dari penerapan nilai Pancasila tersebut. Kampung Pancasila dapat dijadikan sebagai acuan untuk memecahkan masalah yang berkaitan dengan banyaknya sikap intoleransi yang dimiliki oleh para masyarakat di Indonesia. Kampung Pancasila merupakan sebutan yang digunakan bagi desa yang memiliki nilai keberagaman yang dapat saling menghargai satu sama lainnya. Maka dari itu, Kampung Pancasila dapat dijadikan kampung percontohan untuk merevitalisasi, memperkuat, membumikan, dan mempraktikkan secara nyata nilai-nilai Pancasila, seperti: nilai gotong royong, toleransi, saling menghargai, keadilan sosial, dan musyawarah dalam masyarakat.

Istilah Kampung Pancasila mulai poluler dan dikembangkan sejak tahun 2004 di berbagai daerah termasuk Kampung Pancasila yang ada di Dusun Nogosari, Desa Trirenggo, Kabupaten Bantul. Kampung Pancasila di Desa Trirenggo ini sudah dideklarasikan sebagai Kampung Pancasila pada tahun 2004. Deklarasi dilakukan oleh para tokoh adat yang ada di Desa Trirenggo bersama masyarakat sekitar desa. Deklarasi tersebut dilakukan di rumah salah satu warga, yang dijadikan sebagai aula tempat berkumpul untuk bermusyawarah dan membacakan ikrar sebagai Kampung Pancasila. Pendeklarasian Desa Trirenggo sebagai Kampung Pancasila bukan hanya karena masyarakat di desa tersebut dapat hidup berdampingan, tetapi juga dikarenakan kesadaran yang dimiliki oleh masyarakatnya dalam membumikan dan mengembangkan nilai-nilai Pancasila tersebut sangat kuat (Yuriwanto, 2019). Lokasi pengikraran sebagai kampung Pancasila tersebut dapat dilihat dalam gambarl.

Kediaman yang dijadikan sebagai tempat pengikraran tersebut merupakan milik salah satu dosen Fakultas Filsafat, Universitas Gadjah Mada dipilih sebagai tempat yang digunakan untuk musyawarah dan pengikraran Kampung Pancasila, serta membahas mengenai beberapa hal terkait Pancasila. Namun, dalam pengikraran Kampung Pancasila tersebut tidak ditemukan adanya dokumen terkait kepengurusan secara formal dari Kampung Pancasila. Hal tersebut dikarenakan pengikraran Kampung Pancasila hanya secara lisan dan masyarakat hanya mengikuti teks yang sudah dibuat oleh para tetua adat di Kampung Pancasila tersebut. Setelah pengikararan tahun 2004 dilaksanakan, belum ada dilakukan diskusi secara khusus lagi untuk membahas mengenai penyusunan struktur secara formal maupun konteks yang menyangkut pada Kampung Pancasila. Tetapi seiring berjalannya waktu, proses penginternalisasian nilai-nilai Pancasila kampung tersebut dilaksanakan dengan mengalir saja dalam kehidupan di masyarakat hingga saat ini.

Pengikraran Desa Nogosari sebagai Kampung Pancasila pada tahun 2004 memiliki efek yang beragam bagi setiap individu yang 
Gambar 1

Lokasi Pengikraran Kampung Pancasila

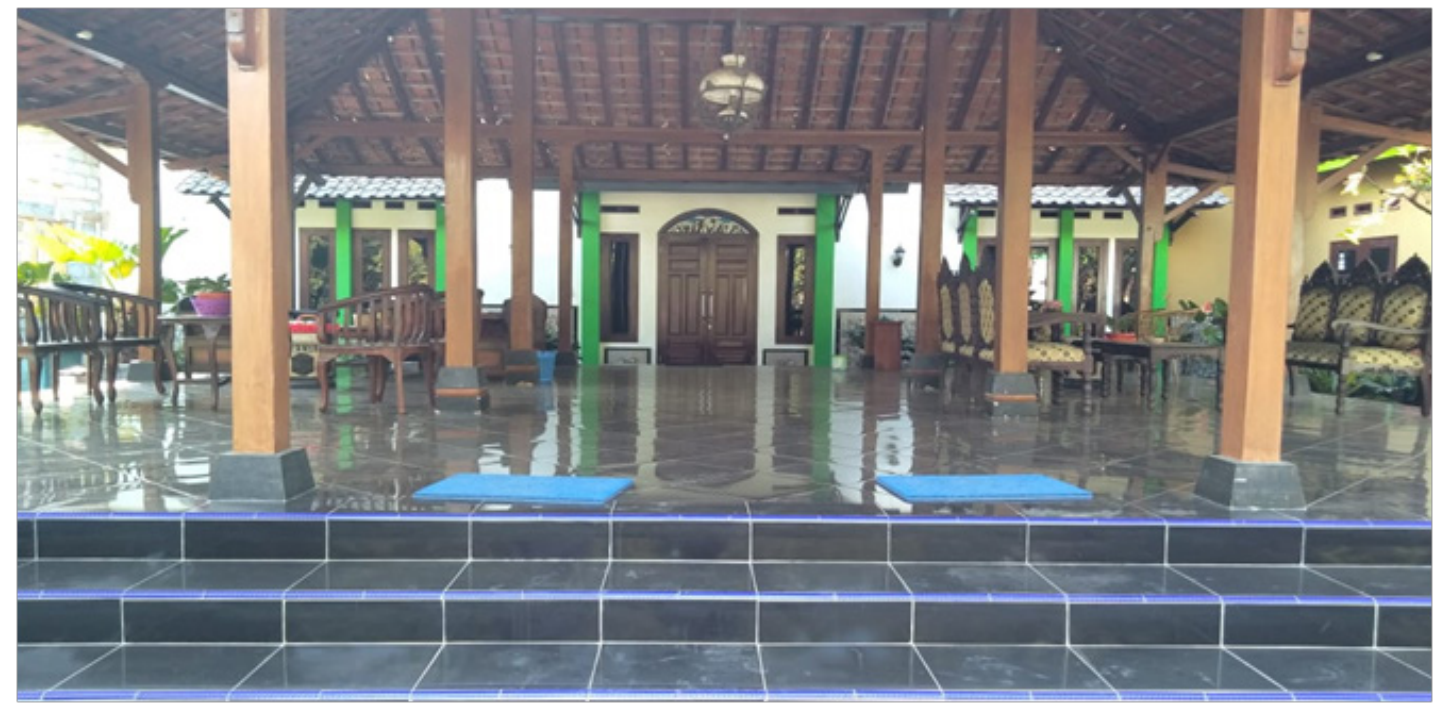

Sumber: Dokumentasi Peneliti, 2019

tinggal di daerah tersebut. Secara keseluruhan, pengaktualisasian nilai-nilai Pancasila dalam lingkup masyarakat khususnya di Kampung Pancasila memiliki respon yang sangat baik. Hal tersebut tampak dari keikutsertaan masyarakat dalam berbagai kegiatan mengenai Pancasila di kampung tersebut begitu menyambut baik, responsive dan banyak yang mengikuti kegiatan yang diadakan mengenai nilai-nilai Pancasila.

Respon tersebut terlihat dari keaktifan warga pada kegiatan, seperti: musyawarah ketua Rukun Tetangga (RT) dan kegiatan gotongroyong tiap minggu. Ketertiban masyarakat dalam mewujudkan Kampung Pancasila juga sangat bagus. Hal tersebut dibuktikan dengan masyarakat dapat bersikap netral dalam memilih pasangan calon pemerintah daerah, tidak ada saling menjatuhkan lawan dan mengunggulkan pilihan. Sikap netral tersebut sampai berefek pada sikap kesadaran sosial masyarakat yang tinggi. Contoh salah satu kejadian saat pilkada berlangsung di Yogyakarta tahun 2019 lalu, para calon sibuk mempromosikan dan berkampanye mengusung masing-masing jagoan di berbagai wilayah. Tak terkecuali kampung Pancasila yang turut memiliki jagoan masing-masing. Namun sikap fanatik tersebut hanya dirasakan secara individu saja. Hal ini disebabkan calon yang diusung tersebut tidak dapat berkampanye di daerah kampung Pancasila yang memang sejak dulunya memiliki kesepakatan sikap netral tersebut, jika terdapat pelanggaran, maka akan diterapkan sanksi adat oleh masyarakat (Yuriwanto, 2019). Kebiasaan baik yang di terapkan tersebut membentuk suatu karakter masyarakat yang demokrasi dan sadar akan tanggung jawabnya untuk meletakkan kepercayaan semua pihak agar patuh atas aturan main yang telah ditentukan (Nurhasim, 2016).

Adanya sikap netral dan tidak menjelekkan pasangan calon politik tersebut membuat wilayah sekitaran Desa Trirenggo menjadi sangat bersih dari banner-banner, spanduk, dan selebaran mengenai pemilihan daerah dan menjadi lebih asri. Gambar 2 adalah daerah Kampung Pancasila yang bersih tersebut.

Respon masyarakat sekitar ketika disebut sebagai Kampung Pancasila sangat baik. Hal tersebut disebabkan masyarakat di daerah tersebut sangat bangga dengan penyebutan 
Isna Sari Rukmana, Samsuri, Darto Wahidin -- Aktualisasi Nilai-Nilai Pancasila Sebagai Contoh Nyata Ketahanan Ideologi (Studi di Kampung Pancasila, Dusun Nogosari, Desa Trirenggo, Kabupaten Bantul,

Daerah Istimewa Yogyakarta)

Gambar 2

Kampung Pancasila yang Bersih

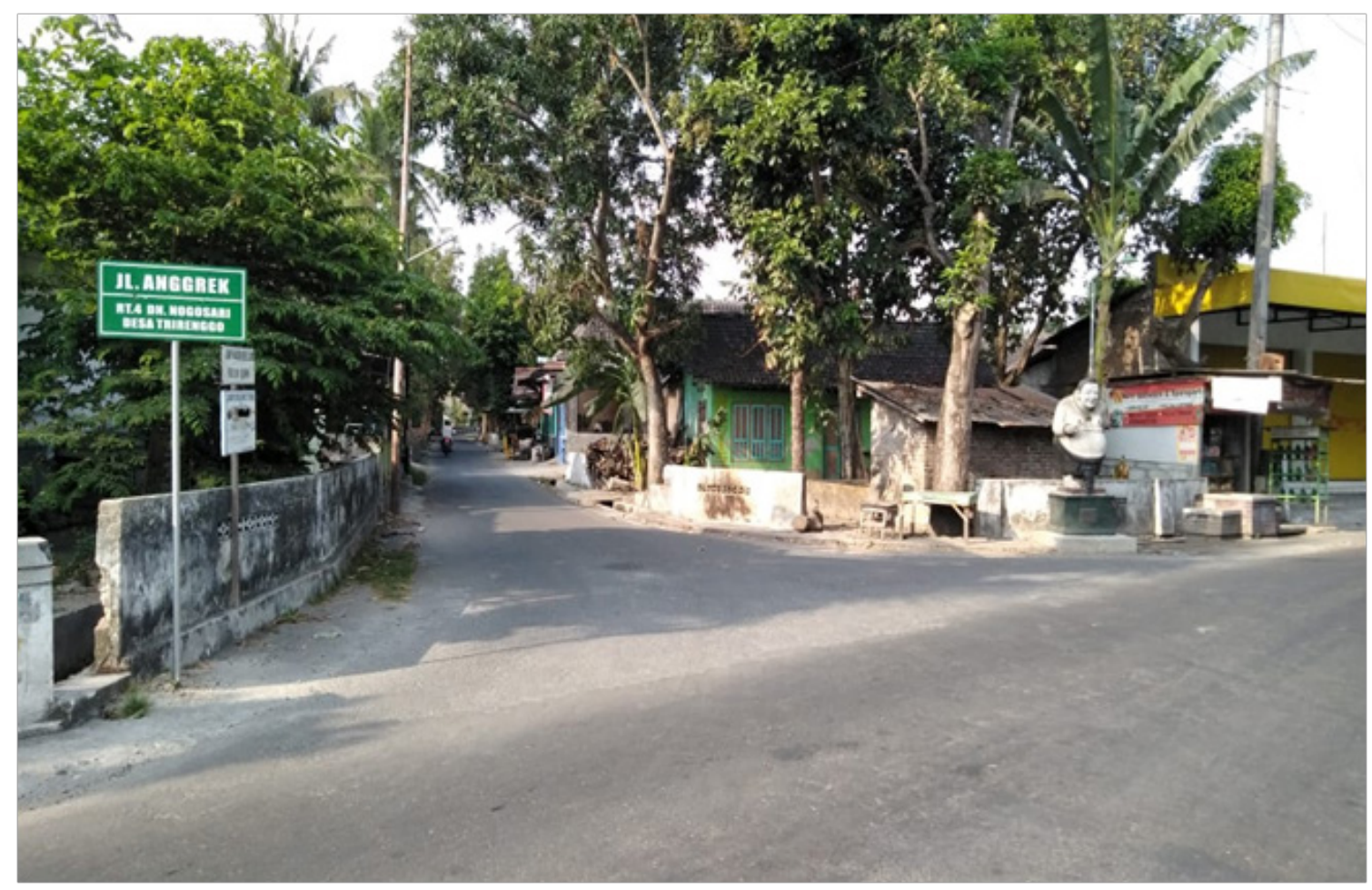

Sumber: Dokumentasi Peneliti, 2019

sebagai Kampung Pancasila. Sudah sejak awal sebelum Desa Trirenggo disebut sebagai Kampung Pancasila, masyarakat sudah hidup dalam kondisi toleransi antar umat beragama. Contoh nyata dari adanya sikap saling toleransi dan keberagaman dari nilai-nilai Pancasila tersebut dapat dicontohkan dengan kegiatan antar umat beragama untuk saling berbagi daging kurban saat Hari Raya Idul Adha. Masyarakat yang beragama Islam juga dengan tangan terbuka menyambut masyarakat non-muslin untuk berkunjung ke rumah-rumah untuk mengucapkan selamat hari raya ataupun sekedar untuk bercengkarama dan bersilaturahmi saja. Rumah ibadah masing-masing pemeluk agama juga dapat didirikan sesuai lokasi mayoritas pemeluk agamanya masing-masing, sehingga belum ada laporan mengenai adanya tindakan intoleransi dan anarkisme yang terjadi antar pemeluk agama di daerah tersebut.
Upaya lebih lanjut yang dilakukan oleh desa selanjutnya adalah dengan menjalin kerjasama untuk mengembangkan Kampung Pancasila sebagai wadah pengaktualisasian nilai-nilai Pancasila dengan pihak lain seperti Pemerintah Daerah Istimewa Yogyakarta belum dilaksanakan sejak diikrarkannya Desa Trirenggo sebagai Kampung Pancasila. Hal tersebut dikarenakan, selama ini Kampung Pancasila yang ada di Desa Trirenggo murni mengembangkan Kampung Pancasila secara mandiri, gotong-royong bersama-sama untuk mewujudkannya. Kepeduliaan dari Pemerintah Dearah Kabupaten Bantul juga masih sangat rendah terhadap Kampung Pancasila, karena selama ini Kabupaten Bantul lebih peduli terhadap pengembangan pariwisata, hasil kerajinan industri kreatif, dan kulinernya.

Namun, ada tokoh-tokoh yang peduli dengan nilai-nilai Pancasila salah satunya dosen 
dari Fakultas Filsafat, Universitas Gadjah Mada yang membantu dalam upaya mengikrarkan Desa Trirenggo menjadi Kampung Pancasila. Selama ini Universitas Gadjah Mada yang dikenal sebagai Universitas Pancasila sangat konsen terhadap pengembangan nilai-nilai Pancasila dalam kehidupan bermasyarakat, berbangsa, dan bernegara. Hal ini dibuktikannya dengan dibentuknya sebuah Kampung Pancasila oleh salah satu dosennya sebagai suatu bentuk kepedulian dan contoh dari pengembangan nilainilai Pancasila yang dapat dijadikan rujukan bagi kampung-kampung lainnya di Indonesia khususnya di Daerah Istimewa Yogyakarta sendiri.

\section{Proses Dan Hasil Pengembangan Nilai- Nilai Pancasila Di Kampung Pancasila}

Kegiatan yang rutin dilakukan dalam upaya mengaktualisasikan nilai-nilai Pancasila di antaranya: gotong royong, musyawarah dusun, diskusi dengan masyarakat, pengumpulan dana bantuan kemanusiaan, arisan rutin, dan musyawarah kebangsaan. Kegiatan gotong royong dilakukan oleh masyarakat dengan tujuan untuk membersihkan wilayah sekitaran desa, membuat daerah sekitar desa menjadi lebih asri dan hijau. Kegiatan gotong royong juga terkadang dilakukan untuk membersihkan banner-banner berbau politik di sekitar wilayah yang memasuki Kampung Pancasila. Kemudian untuk kegiatan musyawarah dusun, biasanya dilakukan oleh tujuh dukuh yang mewakili masyarakat di wilayah yang dukuh ketuai. Ketua dukuh tersebut berkumpul untuk membahas berbagai hal. Termasuk membahas pengaduan dan keluhan yang didapatkan dari masyarakat (gambar 3).

Kegiatan diskusi dukuh ini dilaksanakan seminggu sekali. Tujuan dari kegiatan ini untuk membahas permasalahan daerah sekitar

Gambar 3

Pengaduan Masyarakat Terkait Permasalahan di Kampung Pancasila

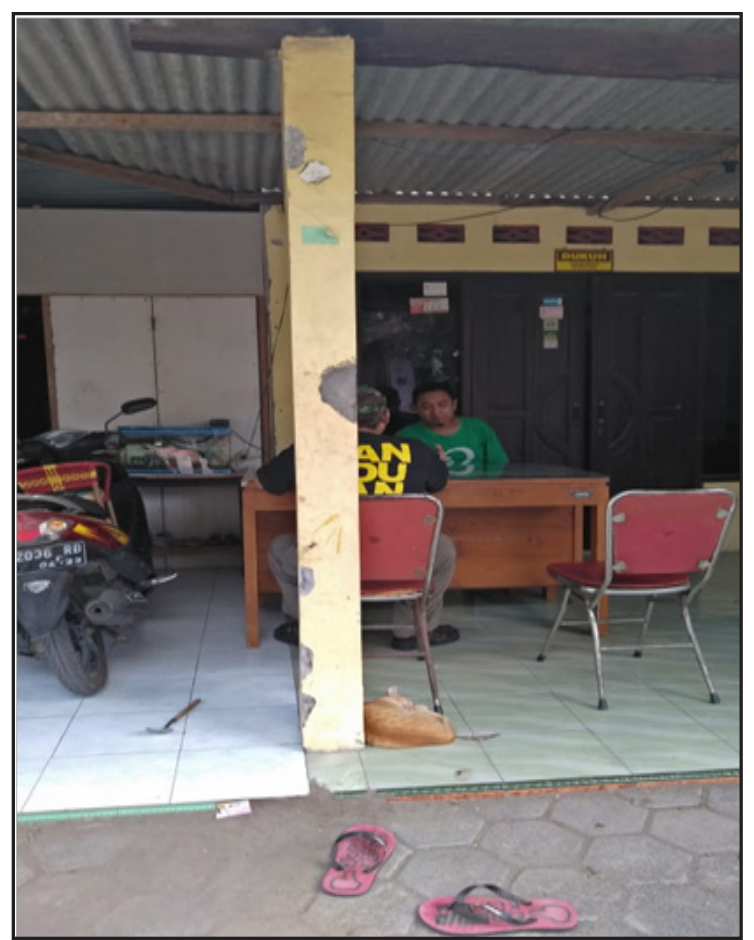

Sumber: Dokumentasi Peneliti, 2019 
Isna Sari Rukmana, Samsuri, Darto Wahidin -- Aktualisasi Nilai-Nilai Pancasila Sebagai Contoh Nyata Ketahanan Ideologi (Studi di Kampung Pancasila, Dusun Nogosari, Desa Trirenggo, Kabupaten Bantul,

Daerah Istimewa Yogyakarta)

Kampung Pancasila jika ada dan bersilaturahmi untuk mempererat persaudaraan antar masingmasing dukuh di wilayah tersebut.Kegiatan diskusi dengan masyarakat merupakan kegiatan yang dilakukan oleh masing-masing dukuh sebagai upaya pelayanan nyata dari dukuh untuk menampung aspirasi, keluhan, pertanyaan, ataupun berbagi pendapat dengan masyarakat mengenai permasalahan yang muncul di daerah sekitar Kampung Pancasila. Dengan kegiatan ini, maka masing-masing dukuh menjadi lebih dekat dengan masyarakat dan dukuh juga mengetahui permasalahan yang terjadi, sehingga bisa dicarikan solusi terbaik terkait pemecahan masalah yang terjadi (gambar 4).

Kegiatan pengumpulan dana bantuan kemanusiaan dilakukan oleh masing-masing Rukun Tetangga(RT) dandukuh di daerah masingmasing untuk kegiatan amal terkait bencana yang terjadi di wilayah Nusantara, ataupun untuk uang kas masing-masing pedukuhan yang kemudian akan digunakan untuk kegiatan tertentu terkait Kampung Pancasila. Kegiatan lainnya arisan rutin yang biasa dilakukan oleh perkumpulan ibu-ibu sekitaran daerah Kampung Pancasila. Kegiatan ini dilakukan dalam rangka silaturahmi dan kumpul-kumpul. Selanjutnya kegiatan musyawarah kebangsaan yang dilakukan untuk mengembangkan nilai-nilai Pancasila pernah dilakukan beberapa kali setelah pengikraran Desa Trirenggo menjadi Kampung Pancasila. Namun setelah itu, kegiatan tersebut tidak pernah dilakukan lagi karena kesibukan masing-masing. Pancasila sebagai ideologi bangsa Indonesia secara utuh telah diterima sebagai landasan dalam haluan berbangsa dan bernegara di Indonesia (Dewantara, dkk, 2019:400; Latief, dkk, 2018:924). Makna ideologi tersebut merujuk pada istilah nilainilai fundamental dan kepercayaan kelompok dan anggotanya (Silalahi dan Yuwono, 2018:59). Pancasila tersebut terdiri dari lima prinsip utama yang berhubungan pada ideologi nasional dan agama. Kelima prinsip tersebut meliputi: prinsip satu ketuhanan yang dipercayai sebagai pencipta tertinggi;

Gambar 4

Diskusi dengan Masyarakat

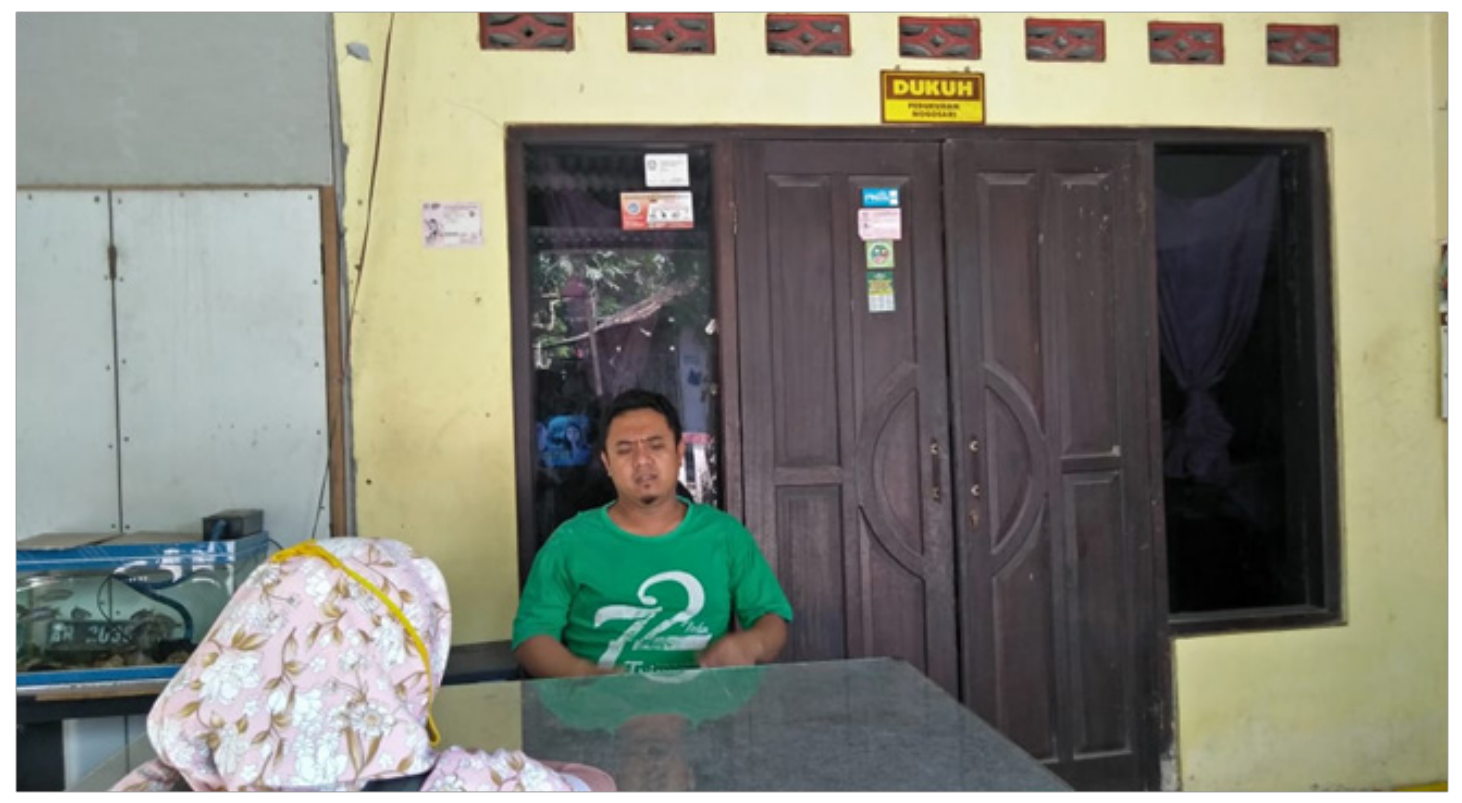

Sumber: Dokumentasi Peneliti, 2019. 
kemanusiaan atau komitmen untuk paham internasionalism; nasionalisme (kesatuan Indonesia; kebijaksanaan yang dilakukan secara sengaja/ representasi; dan keadilan sosial (Fitch dan webb, 1989: 45-46).

Lebih lanjut, Hamidi (2010: 55-51) menyebutkan nilai-nilai dasar yang terkandung dalam Pancasila terdiri dari lima nilai dasar, yaitu nilai ketuhanan, kemanusiaan, persatuan, kerakyatan, dan keadilan. Makna yang terkandung dalam sila pertama meliputi kepercayaan, ketakwaan terhadap Tuhan Yang Maha Esa, kerukunan hidup beragama, dan kebebasan untuk memeluk agama. Nilai yang terkandung dalam sila kedua meliputi kemanusiaan, pengakuan terhadap martabat manusia,dan perlakuan yang adil terhadap sesama manusia. Kemudian, pada silaketiga tentang persatuan bangsa, meliputi: nilai persatuan dan pengakuan terhadap perbedaan yang ada. Kemudian nilai yang terdapat dalam sila keempat, yaitu: kedaulatan, musyawarah. Selanjutnya, sila kelima mengandung nilai keadilan sosial yang dapat dimaknai denggan upaya mengembangkan diri agar sesuai butirbutir Pancasila, kekeluargaan, cinta akan kemajuan dan pembangunan. Pengembangan Pancasila di kampung Pancasila dimaksudkan untuk mengetahui adanya penerapan secara langsung terkait nilai-nilai Pancasila agar tercipta masyarakat yang memiliki moral yang baik dan diharapkan dapat membentukperilaku manusia Indonesia yang seutuhnya dan Pancasilais. Karena pada dasarnya, sikap Pancasilais akan membawa perubahan bagi kepribadian kewarganegaraan Indonesia, khusunya para generasi muda penerus bangsa agar dapat memfilter perubahan dan budaya yang masuk dan akan membawa dampak diberbagai segi kehidupan.
Nilai-nilai yang terkandung dalam Pancasila merupakan bagian dari kepribadian bangsa Indonesia yang telah ada sejak masa penjajahan dulu hingga saat Indonesia menjadi merdeka kini. Hal tersebut secara praktis dapat ditunjukkan melalui penguasaan civic knowledge, civic disposition, dan civic skill yang memiliki tujuan untuk membentuk warga negara yang baik dan turut serta dalam berbagai kegiatan positif untuk mewujudkan cita-cita nasional bangsa Indonesia (Raharjo dkk, 2017). Nilai-nilai yang terdapat dalam Pancasila bukan hanya mengandung nilai budaya bangsa, melainkan juga turut menjadi sumber hukum dan ideologi nasional. Oleh karena itu, nilai-nilai yang terkandung di dalam Pancasila juga harus dijabarkan didalam norma moral, norma pembangunan, norma hukum, dan etika kehidupan berbangsa dan bernegara (Adi, 2016). Pancasila yang akan menjadi dasar dalam semua proses penyelenggaraan negara dalam berbagai bidang, menjadi rujukan bagi seluruh rakyat Indonesia, dan Pancasila akan memberikan kriteria yang jelas mengenai kelayakan suatu sikap yang dilakukan oleh setiap warga negara Indonesia dalam kehidupan baik bermasyarakat, berbangsa maupun bernegara (Kariyadi, 2017).

Nilai-nilai yang dikembangkan di Kampung Pancasila, yaitu nilai sila pertama, yaitu: nilai religius atau ketuhanan; nilai kedua berkaitan dengan toleransi; nilai ketiga terkait dengan persatuan; nilai keempat mengenai musyawarah, dan nilai; dan kelima tentang keadilan sosial. Nilai pertama dikembangkan dengan adanya keberagaman agama yangada di Kampung Pancasila tidak membuat masyarakat antar pemeluk agama di desa tersebut saling memusuhi, melainkan masyarakat dapat hidup secara berdampingan 
Isna Sari Rukmana, Samsuri, Darto Wahidin -- Aktualisasi Nilai-Nilai Pancasila Sebagai Contoh Nyata Ketahanan Ideologi (Studi di Kampung Pancasila, Dusun Nogosari, Desa Trirenggo, Kabupaten Bantul,

Daerah Istimewa Yogyakarta)

tanpa ada pertikaian dan kecemburuan tentang fasilitas yang didapatkan. Selain tempat ibadah yang letaknya hampir berdampingan, wujud nilai-nilai keharmonisan pada sila pertama tersebut juga diwujudkan pada pengembangan nilai kedua, berkaitan dengan toleransi.

Terbukti dengan adanya makam para pemeluk agama yang berbeda namun diletakkan di satu lokasi yang sama secara berdampingan. Hal tersebut menunjukkan bahwa masyarakat di Kampung Pancasila selain hidupnya dapat berdampingan secara harmonis. Perwujudan sila kedua tentang toleransi juga ditunjukkan dengan saling merayakan hari-hari besar pemeluk agama lain. Saat pemeluk agama Islam merayakan Idul Fitri dan Idul Adha, maka masyarakat nonmuslim akan mengunjungi, bersilaturrahmi, dan juga akan mendapatkan bagian hewan kurban pada saat Idul Adha. Begitu juga sebaliknya, jika masyarakat non-muslim merayakan hari besar, maka masyarakat muslim akan mengunjungi masyarakat nonmuslim tersebut untuk menghargai hari perayaan yang tengah dilaksanakan oleh nonmuslim tersebut.

Pengaktualisasian selanjutnya terkait dengan persatuan. Hal tersebut dapat ditunjukkan dengan adanya tolerasi dan saling menghargai membuat masyarakat di Kampung Pancasila menjadi semakin kuat dan erat bukan malah saling menjatuhkan dan menjelekkan satu sama lain. Adanya non-muslim di sekitar perkampungan tidak membuat masyarakat muslim menjadi resah dan terganggu, melainkan biasa-biasa saja dan santai saja, dapat menerima dengan terbuka. Hal ini dikarenakan masyarakat Kampung Pancasila sudah terbiasa dan dapat berbaur dengan masyarakat non-muslim. Selama ini belum ada konflik yang sangat besar terkait dengan permasalahan agama. Kemudian untuk penyelesaian permasalahan sosial yang terjadi di sekitar Kampung Pancasila, akan mendahulukan sanksi sosial yang telah disepakati bersama.

Nilai yang dikembangkan selanjutnya mengenai musyawarah. Hal tersebut tercermin dari berbagai kegiatan yang telah dilakukan oleh Kampung Pancasila, seperti: musyawarah dusun yang dilakukan oleh pedukuhan yang ada di Kampung Pancasila, arisan bulanan, diskusi kebangsaan, dan diskusi dengan masyarakat untuk menyelesaikan masalah dan membuat peraturan berkaitan ketertiban Kampung Pancasila. Salah satunya mengenai aturan terkait tidak diperbolehkannya pemasangan baleho, spanduk dan banner-banner politik calon pasangan baik nasional maupun Daerah Istimewa Yogyakarta di sekitar Kampung Pancasila. Aturan tersebut berbentuk lisan saja, namun dalam musyawarah disosialisasikan dan akhirnya sampai saat ini peraturan tersebut tetap terjaga dan masyarakat dengan sadar dapat dengan tertib mengikutinya untuk mewujudkan Kampung Pancasila yang bersih, tertib, dan nyaman.

Kemudian untuk pengembangan nilai keadilan di Kampung Pancasila dapat dilihat dari persamaan tanpa ada membeda-bedakan status ekonomi, sosial dan strata masyarakatnya. Oleh karena itu, masyarakat di Kampung Pancasila dapat hidup berdampingan tanpa ada perselisihan di antara masyarakatnya. Contoh nyata yang dapat menunjukkan bahwa nilai keadilan sosial di Kampung Pancasila sangat baik adalah masyarakatnya yang netral dalam urusan politik. Masyarakat di Kampung Pancasila netral akan pilihan yang didukungnya, masyarakat yang pro tidak menjatuhkan partai politik lain, contohnya pada politik 
pemilihan calon Dewan Perwakilan Daerah (DPD) di Daerah Istimewa Yogyakarta, salah satu warga merupakan tim sukses dari calon kandidat yang mewakili Daerah Istimewa Yogyakarta ingin melakukan penyuluhan dan sosialisasi calon pasangan DPD tersebut namun diurungkan dengan adanya peraturan yang dibuat secara bersama-sama dan telah disepakati untuk ditaati dan dipahami oleh masyarakat. Oleh karena itu warga yang menjadi tim sukses dari calon kandidat tersebut mengurungkan niatnya untuk melakukan sosialisasi pasangan calon usungannya. Berdasarkan hal tersebut, peraturan bukan hanya untuk memaksakan apa yang telah disepakati dan mengupayakan masyarakat menjadi lebih netral untuk memilih, melainkan tujuan dari adanya peraturan tersebut untuk memupuk sikap adil terhadap pihak manapun, agar tidak tercipta perpecahan dan keresahan dalam lingkup Kampung Pancasila mengenai politik tersebut.

Pengaktualisasian nilai-nilai Pancasila secara umum dapat dibagi menjadi dua yaitu: (1) aktualisasi Pancasila yang bersifat subjektif bahwa perwujudan yang bersifat masif, diletakkan pada masing-masing individu, dan terjadi pada setiap individu; dan (2) aktualisasi yang bersifa objektif yang merupakan pelaksanaan dalam bentuk nyata pada aspek penyelenggaraan negara, realisasi dalam segala aspek kenegaraan dan hukum, termasuk pada bidang legislatif, eksekutif, yudikatif, dan semua bidang kenegaraan terutama hasilnya dalam bentuk peraturan perundang-udangan Indonesia (Sutiyono, 2016). Pengembangan nilai-nilai Pancasila di Kampung Pancasila, Desa Trirenggo tergolong pada Pancasila subjektif dengan penerapan Pancasila secara individuindividu saja. Hal tersebut dikarenakan penerapan nilai-nilai Pancasila di kampung tersebut tidak melibatkan pemerintah dalam membuat ataupun penerapannya. Hampir semua sisi dalam pengembangan nilai tersebut diprakarsai dan dimulai oleh masyarakat di kampung itu sendiri.

Proses dalam mengembangkan nilainilai Pancasila diinternalisasikan kepada masyarakat dalam berbagai kegiatan seharihari. Proses pengikraran tersebut memang ada pertemuan beberapa kali untuk membahas cara yang dilakukan untuk mensosialisikan dan memperkenalkan nilai-nilai tersebut. Namun setelah pengikraran, proses pengembangan nilai-nilai Pancasila langsung pada aktivitas yang dilakukan oleh masyarakat di Kampung Pancasila seperti biasa. Kemudian untuk wujud dari pengembangan nilai-nilai Pancasila tersebut tercermin dari sikap dan tingkah laku masyarakat kampung Pancasila yang jauh lebih tertib, teratur dan saling menghargai satu sama lain. Hasil dari penerapan nilai-nilai Pancasila tersebut membuat masyarakat lebih akur, harmonis, disiplin, saling terbuka dan jauh dari sikap perpecahan dan menjelek-jelekkan pihak lain termasuk pihak non-muslim yang berbeda dan berda satu komplek dengan masyarakat mayoritas muslim di Kampung Pancasila tersebut. Hasil pengembangan nilai-nilai Pancasila di Kampung Pancasila terbilang bagus dan mendapatkan respon yang positif dari warga sekitar.

Masyarakat dapat menjadi lebih toleran, persatuan sangat bagus, kemudian masyarakat lebih terbuka akan informasi, tidak mudah terpengaruh karena memang sudah tertanam di dalam dirinya untuk bersikap netral dan santai saja terhadap politik maupun permasalahan yang muncul di sekitar Kampung Pancasila tersebut. Hasil dari penerapan nilai-nilai Pancasila tersebut membuat masyarakat sekitar 
Isna Sari Rukmana, Samsuri, Darto Wahidin -- Aktualisasi Nilai-Nilai Pancasila Sebagai Contoh Nyata Ketahanan Ideologi (Studi di Kampung Pancasila, Dusun Nogosari, Desa Trirenggo, Kabupaten Bantul,

Daerah Istimewa Yogyakarta)

menjadi lebih tertib dan selalu mengedepankan kepentingan bersama di atas kepentingan pribadi. Walaupun memang peraturan yang dibuat untuk menerapkan nilai-nilai Pancasila tersebut masih kebanyakan peraturan lisan, namun dengan hal itu saja masyarakat sudah dengan sendirinya dapat sadar untuk mematuhi dan menjalankan peraturan tersebut.

Warga negara dalam hal ini berperan sebagai komponen cadangan dan komponen pendukung. Hal tersebut dikarenakan persoalan yang terjadi di negeri ini tidak hanya sebatas pada permasalahan pertahanan dan keamanan yang diurus oleh TNI dan Kepolisian, melainkan hal tersebut juga menjadi tanggungjawab dari warga negara untuk tetap peduli dalam upaya keikutsertaannya dalam mempertahankan negaranya.Secara umum, peranan masyarakat dalam mengembangkan nilai-nilai Pancasila di Kampung Pancasila dengan memberikan teladan, sikap, perilaku, dan memberikan sikap yang baik agar mencerminkan warga negara yang Pancasilais sebagaimana halnya butir-butir yang terkandung dalam Pancasila. Selain itu, peranan masyarakat dalam pengembangan juga sangat penting sebagai upaya menyebarluaskan pengaruh baik mengenai Pancasila terhadap generasi muda yang ada di sekitar wilayah Kampung Pancasila di Desa Trirenggo. Masyarakat di Kampung Pancasila menjadi contoh bagi masyarakat di desa lain untuk dapat menerapkan sikap Pancasila, saling menghargai (toleransi), gotong-royong, musyawarah dan menerapkan nilai keadilan dalam lingkup masyarakat tersebut.

Peranan para pemuda pemudi dalam upaya mengembangkan nilai-nilai Pancasila masih sebatas pada mengikuti dan menjalankan nilai-nilai Pancasila tersebut dan belum membuat suatu gebrakan ataupun inovasi yang dapat mendukung upaya pengembangan nilainilai Pancasila di kampung tersebut menjadi semakin meluas dan semakin membaik kualitasnya. Merujuk pada Pasal 16, UndangUndang Nomor 40 tahun 2009 tentang Kepemudaan, dinyatakan bahwasanya peranan pemuda sebagai kekuatan moral, kontrol sosial, dan agen perubahan. Oleh karena itu, pemuda memiliki tanggung jawab yang besar dalam upaya pembangunan nasional, menjaga NKRI dan menjaga keutuhan Pancasila. Namun pada kenyataannya, pemuda pemudi yang merupakan barisan terdepan dalam menjaga dan mewujudkan bangsa, sangat rentan mengalami tantangan moral yang akan berpengaruh pada tingkat pelemahan kualitas moralitas bangsa kelak. Hal tersebut, pemuda di Kampung Pancasila yang merupakan pemegang tanggungjawab kepemimpinan bangsa di masa depan dapat menjadi solusi terbaik dalam mengatasi permasalahan dari bangsa ini hingga dapat tampil cemerlang sebagai pionir yang handal dalam memberikan solusi yang terbaik, bersikap tangguh dan berjiwa nasionalis untuk menjawab tantangan jaman yang semakin hari semakin maju (Suryaningrat, 2019).

\section{Kendala Yang Dihadapi}

Perkembangan ideologi Pancasila pada saat ini tengah menghadapi permasalahan padaaspek gejala sosial dan dinamika ideologi. Era saat ini menunjukkan adanya peningkatan kebebasan yang sangat beresiko dan dapat mengancam ketahanan ideologi. Beberapa faktor yang dapat melemahkan ketahanan ideologi Pancasila tersebut berawal dari realitas keberagaman, baik secara kebudayaan, suku, bahasa, dan agama. Hal tersebut diwujudkan dengan munculnya sikap-sikap intoleransi, primordialisme, dan sikap egoisme yang sangat 
besar terhadap sesama (Maharani, 2019). Dalam konteks di Negara Indonesia, ancaman, tantangan, dan hambatan turut mengalami pergeseran. Ancaman dan hambatan yang dihadapi oleh bangsa Indonesia bukan lagi seputaran agresi militer dan genjatan senjata antar negara, melainkan permasalahan saat ini lebih terkait pada penjajahan ideologi, politik, ekonomi, dan sosial-budaya (Febrihananto, 2017).

Kendala dalam pengembangan nilainilai Pancasila di Kampung Pancasila dapat terbagi menjadi dua, yaitu kendala personal atau kendala yang berasal dari dalam diri masyarakat itu sendiri. Kemudian kendala dapat dimaknai dengan kurangnya sarana dan prasarana yang turut mendukung pengembangan nilai-nilai Pancasila di Kampung Pancasila tersebut. Kendala personal yang dihadapi oleh masyarakat di Kampung Pancasila pada umumnya masyarakatnya yang terkadang masih bersikap acuh tak acuh pada kegiatan yang terkait pada pengembangan nilai-nilai Pancasila tersebut. Hal tersebut dikarenakan setelah pengikraran sebagai Kampung Pancasila, masyarakat di Kampung Pancasila hanya tahu mengenai Kampung Pancasila secara lisan saja. Sedangkan untuk sosialsiasi lebih lanjut tentang Kampung Pancasila pernah dilakukan beberapa kali, namun seiring berjalannya waktu, pelatihan ataupun sosialisasi terkait Kampung Pancasila sudah jarang dilakukan, sehingga para masyarakat hanya sekedar tahu dan belum benar-benar menjiwai makna dari Pancasila tersebut seutuhnya.

Namun, sebagian besar masyarakat di Kampung Pancasila sudah dapat mengikuti secara sukarela dengan kesadaran penuh menerapkan nilai-nilai tersebut dalam kegiatan sehari-hari. Masyarakat di Kampung Pancasila sudah terbiasa sejak dulu hidup rukun, toleransi, menghormati sesama, dan selalu mengutamakan musyawarah menyebabkan masyarakat di Kampung Pancasila menjadi lebih terbuka dan mengerti dengan sendirinya mengenai nilai-nilai Pancasila tersebut tanpa harus diikrarkan sekalipun oleh tetua adat. Karena hal tersebut sudah menjadi bagian dari diri masyarakat itu sendiri, jadi tanpa paksaan, masyarakat sudah mengerti dan mengerjakan. Hal ini tak lepas dengan adanya beberapa kegiatan yang turut menunjang dalam upaya mengembangkan nilai-nilai Pancasila tersebut seperti musyawarah dukuh, diskusi dengan masyarakat, perkumpulan warga tiap bulannya, diskusi kebangsaan yang kesemuanya turut membantu dalam mensukseskan pengembangan nilai-nilai Pancasila di Kampung Pancasila.

Kemudian untuk kendala teknis yang dihadapi oleh masyarakat di Kampung Pancasila lebih cenderung kepada sarana dan media terkait pempublikasian Kampung Pancasila yang belum lengkap. Hal tersebut dikarenakan memang Kampung Pancasila merupakan lembaga non profit yang memang kelengkapan sarana dan prasarana tidak begitu diperhatikan seutuhnya. Oleh karena itu, kendala yang dihadapi oleh Kampung Pancasila menjadi suatu tantangan tersendiri bagi para pengurus Desa Trirenggo untuk tetap mengupayakan pengembangan Kampung Pancasila ke depannya. Namun, Hal tersebut dapat diatasi dengan kerjasama yang dilakukan oleh seluruh lapisan masyakarat saling membantu, bahu membahu untuk menerapkan nilai-nilai Pancasila. Baik ketua desa, para dukuh, maupunpara masyarakat bersamasama kini dapat mulai perlahan-lahan mulai menerapkan kembali nilai-nilai Pancasila tersebut secara mandiri dan tanpa paksaan 
Isna Sari Rukmana, Samsuri, Darto Wahidin -- Aktualisasi Nilai-Nilai Pancasila Sebagai Contoh Nyata Ketahanan Ideologi (Studi di Kampung Pancasila, Dusun Nogosari, Desa Trirenggo, Kabupaten Bantul,

Daerah Istimewa Yogyakarta)

pihak manapun. Hambatan yang dirasakan lebih pada keikutsertaan pemuda-pemudi dan pemerintah dalam upaya pengembangan nilai-nilai Pancasila di Kampung Pancasila, Desa Trirenggo, Kabupaten Bantul, Daerah Istimewa Yogyakarta.

Harapan dari adanya Kampung Pancasila bahwa masyarakat dapat mempertahankan sikap dan kebiasaan yang bersumber dari Pancasila, masyarakat juga mampu memberikan contoh yang baik dengan bersikap sesuai butir-butir yang ada di dalam Pancasila. Harapan yang khusus juga disampaikan bahwa penyebutan Desa Trirenggo sebagai Kampung Pancasila dapat mengisnspirasi kampung atau desa lain agar menciptakan suasana desa yang sesuai dengan Pancasila. Karena pada dasarnya, dengan adanya Pancasila tersebut hidup menjadi lebih baik dan sesuai pada tuntutan kebaikan juga.

Perwujudan nyata yang dapat dilakukan untuk mencintai Pancasila dapat dilakukan baik secara formal, dalam setiap pembelajaran di sekolah. Kemudian penerapan pada sistem sosial, dan wujud fisik berupa kebudayaan dalam kehidupan masyarakat (Kaelan, 2013). Salah satunya Kampung Pancasila yang dapat dijadikan sebagai sarana yang tepat untuk memupuk kembali nilai-nilai yang bersumber pada Pancasila (Koran Sindo, 2019). Apabila Pancasila memang benar-benar dipahami, dihayati, diinternalisasikan, dan diamalkan secara mandiri, jujur, dan benar pada seluruh aspek kehidupan termasuk dalam upaya melaksanakan gerakan reformasi untuk mewujudkan Indonesia yang lebih baik ke depannya, maka Pancasila dapat menjadi perekat dan mempersatukan kemajemukan bangsa Indonesia (Adi, 2016).

Penelitian yang dilakukan oleh Wulandari (2018) menyebutkan bahwa penanaman nilai Pancasila pada Komunitas Amak-Arak di Kampung Islam Kepaon ditanamkan melalui nilai-nilai yang ada dalam sila pertama. Sedangkan penelitian yang dilakukan oleh Damanhuri (2016) menjelaskan bahwa implementasi nilai-nilai Pancasila di Perkampungan Pancasila Desa Tanjungsari, Kecamatan Pabuaran, Kabupaten Serang, Provinsi Banten diimplementasikan dalam kehidupan masyarakat sehari-hari. Tujuan penerapan nilai-nilai Pancasila sebagai upaya pembentukan karakter bangsa. Dalam pelaksanannya, implemantasi nilai-nilai Pancasila masih belum terlalu banyak dukungan dari masyarakat dan masih kurangnya tingkat kesadaran akan perilaku untuk mencerminkan nilai Pancasila. Oleh karena itu, perlu adanya dukungan dan dorongan dari berbagai pihak yang berwenang di dalamnya. Selanjutnya penelitian yang dilakukan oleh Chayati dan Setyowati (2016) menyatakan bahwa eksistensi nilai-nilai Pancasila di Desa Balun, Kecamatan Turi, Kabupaten Lamongan berjalan dengan baik. Hal ini terbukti dari tingkat toleransi antar umat beragama di daerah tersebut yang masih terjaga.

Perbedaan dari penelitian dari (Damanhuri, 2016; Wulandari, 2018; dan Chayati, 2016) dengan penelitian ini terletak pada lokasi penelitian, nilai-nilai yang diterapkan untuk mengembangan nilainilai Pancasila tersebut. Penelitian yang dilakukan oleh Wulandari menyebutkan bahwa pengembangan nilai Pancasila di Kampung Amak-Arak terfokus pada sila pertama, yaitu religius. Sedangkan pada penelitian yang dilakukan di Kampung Pancasila lebih bervariasi dan memuat keseluruhan kelima sila yang ada di dalam Pancasila. Selanjutnya penelitian Damanhuri (2016) memiliki penjelasan yang lebih umum dibandingkan 
penelitian yang dilakukan di Kabupaten Bantul ini. Jika penelitian Damanhuri (2016) menginternalisasikan dalam kehidupan seharihari, maka dalam penelitian ini dijabarkan bahwa penginternalisasian nilai-nilai Pancasila bukan hanya sekedar pembiasaan saja, melainkan juga dikaitkan pada kegiatan yang berhubungan dengan penguatan nilai-nilai Pancasila tersebut, seperti diskusi kebangsaan, perkumpulan para dukuh, dan lain sebagainya. Kemudian untuk penelitian yang dilakukan oleh Chayati dan Setyowati (2016) berfokus pada tiga nilai yang dijadikan acuan, yaitu toleransi antar umat beragama, gotong-royong, dan musyawah. Sedangkan dalam penelitian ini mencakup pada pengaktualisasian kelima nilai Pancasila yang ada di Kampung Pancasila yang ada di Dusun Nogosari, Desa Trirenggo, Daerah Istimewa Yogyakarta.

\section{SIMPULAN}

Berdasar uraian tersebut di atas dapat ditarik simpulan sebagai berikut.

Pertama, pengembangan nilai-nilai Pancasila merupakan hal yang sangat penting untuk dilakukan pada setiap sisi kehidupan termasuk dengan mewujudkan Kampung Pancasila untuk mewujudkan masyarakat yang harmonis, damai dan jauh dari perselisihan. Kampung Pancasila di Desa Trirenggo ini sudah dideklarasikan sebagai Kampung Pancasila pada tahun 2004. Deklarasi tersebut dilakukan oleh para tokoh adat yang ada di Desa Trirenggo tersebut bersama masyarakat sekitar desa. Respon masyarakat terkait pengembangan nilai-nilai Pancasila dalam lingkup masyarakat khususnya di Kampung Pancasila memiliki sambutan yang sangat baik. Hal tersebut tampak dari keikutsertaan masyarakat dalam berbagai kegiatan mengenai Pancasila di kampung tersebut begitu menyambut baik, responsif dan banyak yang mengikuti kegiatan yang diadakan mengenai nilai-nilai Pancasila.

Kedua, kegiatan yang rutin dilakukan dalam upaya mengembangkan nilai-nilai Pancasila di Kampung Pancasila di Desa Trirenggo dengan melalui gotong royong, musyawarah dusun, diskusi dengan masyarakat, pengumpulan dana bantuan kemanusiaan, arisan rutin, danmusyawarah kebangsaan. Nilai-nilai yang dikembangkan di Kampung Pancasila adalah religius atau ketuhanan, toleransi, persatuan, musyawarah, dan keadilan sosial. Proses dalam mengembangkan nilai-nilai Pancasila diinternalisasikan kepada masyarakat dalam berbagai kegiatan yang dibuat untuk menunjang pengembangan nilai-nilai Pancasila tersebut. Hasil pengembangan nilai-nilai Pancasila di Kampung Pancasila terbilang bagus dan mendapatkan respon yang positif dari warga sekitar. Masyarakat dapat menjadi lebih toleran, persatuan sangat bagus, kemudian masyarakat lebih terbuka akan informasi, tidak mudah terpengaruh karena memang sudah tertanam di dalam dirinya untuk bersikap netral dan santai saja terhadap politik maupun permasalahan yang muncul di sekitar Kampung Pancasila tersebut. Sejak dideklarasikan tahun 2004 tidak mengalami hambatan yang berarti dalam mengembangkan Kampung Pancasila. Harapan yang diinginkan pada masa yang akan datang dari adanya Kampung Pancasila bahwa masyarakat dapat terus mempertahankan sikap dan kebiasaan yang bersumber dari Pancasila, agar masyarakat mampu memberikan contoh dan dapat bersikap sesuai butir-butir yang ada di dalam Pancasila. Supaya ideologi Pancasila tetap terus bertahan di tengah arus era revolusi industri 4.0.

Selanjutnya, direkomendasikan beberapa hal sebagai berikut. 
Isna Sari Rukmana, Samsuri, Darto Wahidin -- Aktualisasi Nilai-Nilai Pancasila Sebagai Contoh Nyata Ketahanan Ideologi (Studi di Kampung Pancasila, Dusun Nogosari, Desa Trirenggo, Kabupaten Bantul, Daerah Istimewa Yogyakarta)

Pertama, pemerintah pusat dan daerah hendaknya lebih terlibat dan memperhatikan dalam upaya pengembangan nilai-nilai pancasila di Kampung Pancasila. Pemerintah hendaknya memberikan bantuan baik berupa dana, fasilitas, ataupun bimbingan dan penyuluhan lebih dalam terkait penginternalisasikan nilai-nilai Pancasila di Kampung Pancasila.

Kedua, masyarakat harus lebih aktif dalam mempromosikan Kampung Pancasila kepada masyarakat luas agar lebih mengetahui informasi terkait Kampung Pancasila di Dusun Nogosari, Desa Trirenggo, Kabupaten Bantul, Daerah Istimewa Yogyakarta.

Ketiga, peran pemuda dalam mengembangkan nilai-nilai Pancasila di Kampung Pancasila hendaknya lebih digiatkan lagi agar menjadi lebih baik ke depannya.

\section{DAFTAR PUSTAKA}

Adi, P., 2016, 'Pembudayaan Nilai-Nilai PancasilaBagi Masyarakat Sebagai Modal Dasar Pertahanan Nasional NKRI, Jurnal Moral Kemasyarakatan, Vol. 1, No. 1, hh. 37-50.

Al-Jihad, R. Saddam, 2018, 'Ideologi Pancasila Dunia: Sintesis, Kapitalisme, Sosialisme, dan Islam', Jakarta: PT Pusataka Alvabet.

Anggusti, M. dan H. Siallagan, 2019, 'Environmentally Friendly Technology Development At Era Industrial Revolution 4.0 In Indonesia, IOP Conference Series: Materials Science and Engineering, 3rd Nommensen International Conference on Technology and Engineering, No. 725, hh. 1-6

Armawi, Armaidy, dan Darto Wahidin, 2018, 'Ketahanan Nasional dan Bela Negara', Majalah Wira, Edisi Khusus
Kementerian Pertahanan Republik Indonesia.

Armawi, Armaidy, 2019, 'Nasionalisme dan Dinamika Ketahanan Nasional', Yogyakarta,: Gadjah Mada Uniuversity Press.

Asmaroini, A., P., 2016, 'Implementasi NilaiNilai Pancasila Bagi Siswa di Era Globalisasi', CITIZENSHIP: Jurnal Pancasila dan Kewarganegaraan, Vol. 4, No. 2, hh. 440-450.

Budiwibowo, S., 2016, 'Revitalisasi Pancasila dan Bela Negara dalam Menghadapi Tantangan Global Melalui Pembelajaran Berbasis Multikultural',CITIZENSHIP: Jurnal Pancasila dan Kewarganegaraan, Vol. 4, No. 2, hh. 566-585.

Chayati, D, N, dan Rr. N. Setyowati, 2016, 'Eksistensi Nilai-Nilai Pancasila Di Desa Balun Kecamatan Turi Kabupaten Lamongan', Kajian Moral dan Kewarganegaraan, Vol. 2, No. 4, hh. 455-469.

Damanhuri, Hardika, L.W. Alwan, B. F., dan I.N. Rahman, 2016, 'Implementasi Nilai-Nilai Pancasila Sebagai Upaya Pembangunan Karakter Bangsa (Studi Kasus di Kampung Pancasila Desa Tanjung Sari, Kecamatan Pabuaran, Kabupaten Serang)', Untirta Civic Education Journal (UCEJ), Vol. 1, No. 2, hh. 185-198.

Dewantara, J, A., I.F. Suhendri, R. Rosyid, dan T.S. Atmaja, 2019, 'Pancasila as Ideology and Characteristics Civic Education in Indonesia. International Journal for Educational and Vocational Studies, Vol. 1, No.5, hh. 400-405.

Dewi, D, K., dan Sunarso., 2019, 'Strategi Pembentukan Ketahanan Pribadi Siswa Berbasis Nilai-Nilai Pancasila Untuk 
Membangun Kesadaran Bernegara (Studi Di SMA Taruna Nusantara Magelang Jawa Tengah)', Jurnal Ketahanan Nasional, Vol. 26, No. 1, hh. 40-54.

Febrihananto, E., W., I. Abdullah, dan A. Zubaidi, 2017, 'Partisipasi Pemuda Purna Paskibraka Indonesia dalam Kegiatan Bela Negara dan Pengaruhnya Terhadap Ketahanan Wilayah (Studi Tentang Purna Paskibraka Indonesia Kabupaten Klaten, Provinsi Jawa Tengah)', Jurnal Ketahanan Nasional, Vol. 23, No. 1, hh. 68-85.

Fitch, R, M., dan S.A. Webb, 1989, 'Cultural Immersion in Indonesia through Pancasila: State Ideology', The Journal of Educational Thought (JET) / Revue de la Pensée Éducative, Vol. 23, No. 1, hh. 44-51.

Fitriasari, P, D., 2019, 'Partisipasi Masyarakat Dalam Kesenian Soreng Guna Meningkatkan Ketahanan Budaya (Studi Di Desa Banyusidi, Kecamatan Pakis, Kabupaten Magelang, Jawa Tengah)', Jurnal Ketahanan Nasional, Vol. 25, No.3, hh. 409-420.

Hamidi, Jazim, dan M. Lutfi, 2010, 'Civic Education; Antara RealitasPolitik dan Implementasi Hukumnya, Jakarta: Gramedia Pustaka Utama.

Huda, M, C., 2018, 'Strengthening Pancasila As National Ideology To Implementate The Balancing Values To Improve Law's Application In Indonesia', Jurnal Pembaharuan Hukum, Vol. 5, No.1, hh. 1-12.

Kaelan, 2002, 'Filsafat Pancasila: Pandangan Hidup Bangsa Indonesia' Yogyakarta: Paradigma.
Kaelan, 2013, 'Negara kebangsaan Pancasila', Yogyakarta: Paradigma.

Kaelan, 2015, 'Liberalisasi Ideologi Negara Pancasila', Yogyakarta: Paradigma.

Kariyadi, D., W. Suprapto, 2017, 'Membangun Kepemimpinan Berbasis Nilai-Nilai Pancasila dalam Perspektif Masyarakat Multikultural', CITIZENSHIP: Jurnal Pancasila dan Kewarganegaraan, Vol. 5, No. 2, hh, 86-96.

Kiel, D., J.M. Muller, C. Arnold, dan K.I.Voigt, 2017, 'Sustainable Industrial Value Creation: Benefits And Challenges Of Industry 4.0', International Journal of Innovation Management, Vol. 21, No.08, hh. 1-34.

Koran Sindo, 2019, 'Kampung Pancasila Wujudkan Masyarakat Bernilai Luhur Pancasila'. $<$ https://nasional.sindonews. $\mathrm{com} / \mathrm{read} / 1378901 / 15 / \mathrm{kampung}$ pancasila-wujudkan-masyarakatbernilai-luhur-bangsa-1550195995>. diakses pada hari Jum'at, 18 Oktober 2019, pukul 16:54 WIB.

Kymlicka, W., 2003,'Kewarganegaraan Multikultural', Jakarta: LP3ES.

Latif, Yudi, 2011, 'Negara Paripurna', Jakarta: Gramedia Pustaka Utama.

Latif, Yudi, 2018, 'Wawansan Pancasila: Bintang Penuntun untuk Pembudayaan', Jakarta: Mizan

Latif, Yudi, 2018, 'The Religiosity, Nationality, and Sociality of Pancasila: Toward Pancasila through Soekarno's Way', Studia Islamika: Indonesian Journal for Islamic studies, Vol. 25, No.2, hh. 207-244.

Letief, A., M. Nadir, T. Pangalila, A.L.Lonto, T. Suyanto, dan Warsono., 2018, 'Revitalizing the Value of Pancasila in the Development of the Character of 
Isna Sari Rukmana, Samsuri, Darto Wahidin -- Aktualisasi Nilai-Nilai Pancasila Sebagai Contoh Nyata Ketahanan Ideologi (Studi di Kampung Pancasila, Dusun Nogosari, Desa Trirenggo, Kabupaten Bantul, Daerah Istimewa Yogyakarta)

Indonesian Citizens', 1st International Conference on Social Sciences (ICSS 2018), Advances in Social Science, Education and Humanities Research, Vol. 226, hh. 923-926.

Lonto, A, L., dan T. Pangalila, 2019, 'The existence of Pancasila Values in the Disrupted Era', Proceedings 1st International Conference on Education Social Sciences and Humanities (ICESSHum 2019), Vol. 335, hh. 145-149.

Maharani, S, D., Surono, H. Sutarmanto, dan A. Zubaidi, 2019, 'Indeks ketahanan Ideologi Pancasila', Jurnal Ketahanan Nasional, Vol. 25, No. 2, hh. 277-294. Mubah, A., S., 2011'Strategi Meningkatkan Daya Tahan Budaya Lokal dalam Menghadapi Arus Globalisasi',Jurnal Unair, Vol. 24, No. 4, hh. 302-308.

Nurcahyono, H., 2018, 'Pendidikan Multikultural Di Indonesia: Analisis Sinkronis Dan Diakronis', Habitus: Jurnal Pendidikan, Sosiologi dan Antropologi, Vol. 2, No. 1, hh. 105-115. Nurhasim, M., 2016, 'Konflik Dalam Pilkada Langsung Studi Tentang Penyebab dan Dampak Konflik', Jurnal Penelitian Politik, hh. 105-117.

Peraturan Menteri Dalam Negeri Republik Indonesia No 81 Tahun 2015 Tentang Evaluasi Perkembangan Desa dan Kelurahan.

Prasetyo,B., dan U.Trisyanti, 2018, 'Revolusi Industri 4.0 dan Tantangan Perubahan Sosial', Prosiding SEMATEKSOS 3 Strategi Pembangunan Nasional Menghadapi Revolusi Industri 4.0, No, 5. hh. 22-27.

Raharjo, A. Armawi, D. Soerjo, 2017, 'Penguatan Civic Literacy dalam Pembentukan Warga Negara yang
Baik (Good Citizen) dan Implikasinya terhadap Ketahanan Pribadi Warga Negara Muda (Studi tentang Peran Pemuda HMP PPKn Demokratia pada Dusun Binaan Mutiara Ilmu di Kecamatan Jebres, Kota Surakarta, Provinsi Jawa tengah). Jurnal Ketahanan Nasional, Vol. 23, No. 2, hh. 175-198. Rivelino, 2017, 'Revolusi Nilai Pancasila dalam Mengatasi Penyalagunaan Narkotika di Indonesia', Jurnal Inspirasi, Vol. 8, No. 2, hh. 91-99.

Rozikin, M., 2019, 'Memperkuat Ketahanan Masyarakat Berbasis Social Capital Pada Era Otonomi Desa (Studi Di Desa Pandansari, Kecamatan Ngantang, Kabupaten Malang)', Jurnal Ketahanan Nasional, Vol. 25, No. 2, hh. 204-225.

Sacipto, R., 2018, 'Penguatan Integrasi Nasional terhadap Masyrakat Desa di Era Disrupsi Berlandaskan Asas Pancasila', Prosiding Seminar Nasional Jurusan Politik dan Kewarganegaraan, Vol. 2, No. 1, hh. 156-164.

Saputra, I., 2017, 'Aktualisasi Nilai Pancasila Sebagai Kunci Mengatasi Penyalahgunaan Narkoba di Indonesia', JPK: Jurnal Pancasila dan Kewarganegaraan, Vol. 2, No. 2, hh. 25-35.

Setiawan, S. R., D., 2018,'Survei: dalam 13 Tahun, Persentase Publik Pro Pancasila Terus Menurun', Kompas. Com $<$ https://nasional.kompas.com/ $\mathrm{read} / 2018 / 07 / 17 / 15580981 / \mathrm{survei}-$ dalam-13-tahun-persentase-publik-propancasila-terus-menuru $>$. diakses pada hari Jum'at, 18 Oktober 2019, pukul 18:31WIB.

Silalahi, R, dan U. Yuwono, 2018, 'The Sustainability of Pancasila in Indonesian 
Education System: A Critical Discourse Analysis of Legal Texts on Education', Research in Social Sciences and Technology (RESSAT), Vol. 3, No.2, hh. 58-78.

Siregar, R., E.A.B.Putera, Z. Djumadin, dan Y.Wibisono, 2019, 'Pancasila As Ideology: Values And Practices In Society In The Era Of Globalization', Asian Journal of Social Sciences \& Humanities, Vol. 8, No.4, hh. 1-13.

Sudjana, 2018, 'Hakikat Adil Dan Makmur Sebagai Landasan Hidup Dalam Mewujudkan Ketahanan Untuk Mencapai Masyarakat Sejahtera Melalui Pembangunan Nasional Berdasarkan Pancasila', Jurnal Ketahanan Nasional, Vol. 24, No. 2, hh. 135-151.

Sukmayadi, T, 2018, 'Nilai-Nilai Kearifan Lokal dalam Pandangan Hidup Masyarakat Adat Kampung Kuta', Jurnal Pancasila dan Kewarganegaraan (JPK), Vol. 3, No. 1, hh. 19-29.

Suryaningrat, W., A. Armawi, dan D. Soerjo, 2019, 'Internalisasi Bela Negara dalam Pembinaan Kegiatan Pemuda Purna Paskibraka Kabupaten Bandung untuk Pembentukan Ketahanan Pribadi', Jurnal Ketahanan Nasional. Vol. 25, No. 1, hh. 36-55.
Sutiyono, 2016, 'Reaktualisasi Pancasila dalam Membentuk Good Citizenship di Era Global', Seminar Nasional Hukum, v $\backslash$ Vol. 2. No.1, hh. 585-598.

Undang-Undang Nomor 40 Tahun 2009 Tentang Kepemudaan

Viska, 2019, 'Jiwa Pancasila Penting di Era Perkembangan Teknologi, Harus Diamalkan dan Diperjuangkan', $<$ https://kominfo.go.id/content/ detail/20401/jiwa-pancasila-pentingdi-era-perkembangan-teknologi-harusdiamalkan-dan-diperjuangkan/0/ sorotan_media $>$. diakses pada hari Jum'at, 18 Oktober 2019, pukul 18:28 WIB.

Widiseuseno, I., 2014, 'Azas Filosofis Pancasila Sebagai Ideologi Dan Dasar Negara', HUMANIKA, Vol. 20, No.2, hh. 62-66.

Winarno, dan Raharjo, 2018, 'Realisasi Pancasila dalam Rangka Mewujudkan Ketahanan Ideologi Bangsa',Prosiding Seminar Nasional Jurusan Politik dan Kewarganegaraan, Vol. 2, No. 1, hh. 219-238.

Wulandari, R., 2018, 'Wujud Penanaman Nilai Pancasila pada Komunitas "Amak-Arak" Kampung Islam Kepaon', Gulawentah: Jurnal Studi Sosial, Vol. 3, No. 2, hh. 100-127. 